\title{
Brown adipose tissue in humans: regulation and metabolic significance
}

\author{
Moe Thuzar ${ }^{1,2}$ and Ken K Y Ho ${ }^{1,2}$ \\ ${ }^{1}$ Department of Endocrinology and Diabetes, Princess Alexandra Hospital, Brisbane, Queensland, Australia and \\ ${ }^{2}$ School of Medicine, University of Queensland, Brisbane, Queensland 4102, Australia
}

Correspondence should be addressed to K K Y Ho

Email

k.ho@uq.edu.au

\begin{abstract}
The recent discovery that functional brown adipose tissue (BAT) persists in adult humans has enkindled a renaissance in metabolic research, with a view of harnessing its thermogenic capacity to combat obesity. This review focuses on the advances in the regulation and the metabolic significance of BAT in humans. BAT activity in humans is stimulated by cold exposure and by several factors such as diet and metabolic hormones. BAT function is regulated at two levels: an acute process involving the stimulation of the intrinsic thermogenic activity of brown adipocytes and a chronic process of growth involving the proliferation of pre-existing brown adipocytes or differentiation to brown adipocytes of adipocytes from specific white adipose tissue depots. BAT activity is reduced in the obese, and its stimulation by cold exposure increases insulin sensitivity and reduces body fat. These observations provide strong evidence that BAT plays a significant role in energy balance in humans and has the potential to be harnessed as a therapeutic target for the management of obesity.
\end{abstract}

\section{Introduction}

Brown adipose tissue (BAT) is a thermogenic organ that dissipates nutrient energy as heat, protecting animals from hypothermia and obesity. The thermogenic property of BAT is conferred by a unique protein, called uncoupling protein 1 (UCP1), located in the inner mitochondrial membrane of brown adipocytes (1). By mediating the proton conductance into the mitochondrial matrix, UCP1 uncouples mitochondrial oxidation from ATP synthesis, resulting in the generation of heat instead of ATP (1).

It was traditionally believed that BAT was present only in infants. However, over the last decade, metabolic imaging based on the use of an isotopic glucose analogue,

Invited Authors' profile

Ken Ho MD, FRACP, FRCP is the Professor of Medicine, University of Queensland and Chair, Centres for Health Research, Princess Alexandra Hospital, Brisbane, Australia. His research interests are pituitary disorders, neuroendocrine regulation of substrate and energy metabolism and endocrinology of sports.

Moe Thuzar is a Clinical Endocrinologist at the Princess Alexandra Hospital and senior lecturer at the School of Medicine, University of Queensland, Brisbane, Australia. She is undertaking postgraduate doctoral studies on the endocrine regulation of human brown adipose tissue and effect on energy metabolism. She is the recipient of the Outstanding Abstract Award 2016 presented by the Endocrine Society.

(C) 2016 European Society of Endocrinology Printed in Great Britain
Published by Bioscientifica Ltd

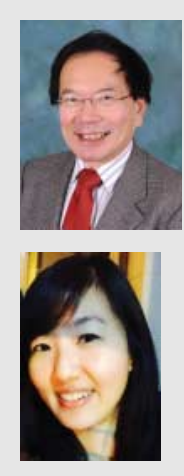


has provided conclusive evidence that BAT exists in adult humans $(2,3,4)$. This technique of positron emission tomography combined with computed tomography (PET-CT), has demonstrated the avid uptake of fluorodeoxy-glucose (FDG), into tissue of fat density which on biopsy displayed the characteristics of $\operatorname{BAT}(2,4,5)$. BAT depots are located in the supraclavicular, neck, paravertebral and perinephric regions of adult humans.

Much research effort has gone into investigating the biology of BAT in humans. This paper will review recent advances in the regulation and metabolic significance of BAT in humans.

\section{Two types of BAT}

Studies in rodents have provided strong evidence for two types of BAT, 'classical' and 'brite', which differ in developmental origin but display similar biological properties $(6,7,8)$. Classical BAT, located in the interscapular region, originates from stem cells of muscle lineage (9). Brite cells (brown in white; also termed 'beige') are brown adipocyte-like cells derived from white adipose cell origin, and the formation of brite cells within the white adipose depot (WAT) is referred to as 'browning' $(10,11,12)$. Molecular/gene signatures have been identified for classical brown, brite and white adipocytes in rodents and humans $(8,13,14)$, the details of which are out of scope for this review. In rodents, brite adipocytes are located in the inguinal and retroperitoneal WAT depots $(7,12)$. BAT depots around the neck and in the supraclavicular regions of adult humans consist of a mixed population of both classical brown and brite cells $(8,13,15)$. In this review, these depots will be simply referred to as BAT and identification of increased UCP1 expression in typical WAT depots will be reported as browning.

Two processes have been proposed for browning. Some researchers report that the cells arise directly from transdifferentiation of mature white adipocytes $(10,16)$ while others postulate they arise from a distinct precursor cell population within the WAT depot $(17,18)$. The browning of white adipose tissue is regarded as a process of huge potential for harnessing the metabolic capacity of BAT.

\section{Regulation of BAT in humans}

BAT is regulated by environmental and nutritional factors that are mediated by neural and endocrine mechanisms. Some of these factors control the thermogenic activity, others regulate BAT mass and some may affect both processes. For example, in rodents, cold exposure stimulates
BAT function acutely $(3,4)$ but over a protracted period increases BAT mass, a process involving proliferation of classical brown adipocytes $(19,20)$ and expansion of brite depots from the browning phenomenon $(10,11,12)$.

\section{Assessment of BAT and browning}

PET imaging allows for non-invasive study of human BAT activity. The avidity of FDG uptake on PET imaging reflects the UCP1 content on tissue analysis (2). PET-CT also allows for the quantification of the volume of active BAT. Some investigators have interpreted an increase in active BAT volume on PET-CT as 'recruitment' of BAT $(21,22,23$, 24). This terminology implies that the intervention has increased the abundance or mass of BAT. However, the increase in BAT volume on a scan may simply reflect the stimulation of BAT depot function beyond a detectable threshold of quantification. Thus, PET-CT cannot differentiate BAT activity from abundance as the mechanism underlying a change in BAT volume. Quantification of BAT mass will require a technique which can identify BAT tissue mass/volume, independent of activity. To date, such a technique has not been established non-invasively. Similarly, determination of the browning process is only possible by direct tissue examination at this stage.

The following sections cover regulation of BAT in humans.

Cold exposure $\bullet$ Cold exposure stimulates BAT activity. There is a higher prevalence of BAT in scans undertaken in winter than in summer $(25,26,27,28)$. BAT FDG uptake is increased when subjects are precooled before scanning $(3,4,29)$ and lower with pre-warming $(30,31,32)$. Coldstimulated increase in glucose uptake is accompanied by a parallel increase of oxidative capacity $(21,33)$, oxygen consumption (34) and blood flow $(34,35)$ in human BAT.

In addition to stimulating activity, prolonged cooling increases BAT mass and induces browning of WAT in rodents $(10,11,12,19,20)$. The evidence as to whether prolonged cold exposure promotes BAT mass and browning in humans is not established conclusively. Cold exposure for 2-6 weeks markedly increases the avidity of FDG uptake and volume of active BAT $(21,22,23,24)$. However, it is not possible to determine from these studies whether the increase in detectable volume arises from enhanced activity or from an expanded cell mass. Indirect evidence that prolonged cold stimulus can increase BAT mass in humans comes from the necropsy finding of a high amount of BAT around the neck of Finnish outdoor workers (36). 
Three studies have investigated whether browning occurs in humans after cold acclimatisation $(22,23,37)$. Two studies employed cooling at $15^{\circ} \mathrm{C}$ for $6 \mathrm{~h}$ per day for 10 days $(23,37)$, while the other at $19{ }^{\circ} \mathrm{C}$ for at least $10 \mathrm{~h}$ per day for 1 month (22). None of the studies found evidence of browning in biopsies of subcutaneous abdominal WAT under these cooling conditions $(22,23,37)$. However, subcutaneous abdominal WAT is not recognised as a depot harbouring brite precursors in humans and examination of other depots is warranted.

Cold stimulates BAT activity via the sympathetic nervous system (SNS). SNS activation is reflected by an increase in plasma and urinary noradrenaline levels in cold-exposed subjects $(35,38,39,40,41)$. Denervation of sympathetic nerves abrogated the cold-induced changes in BAT activity in animals (42), providing strong evidence that SNS plays a pivotal role in mediating the stimulatory effect of cold on BAT.

SNS and catecholamines - BAT is innervated by the sympathetic nerves (43), under central control of the hypothalamus (1). The SNS regulation of BAT is mediated by the release of noradrenaline (NA) from the nerve endings (1). In addition to locally released noradrenaline, circulating catecholamines also regulate BAT activity. The evidence comes from studies of patients with pheochromocytoma who exhibit widespread uptake of glucose in many depots not normally seen in routine imaging $(44,45)$. BAT activity correlates with the levels of circulating catecholamines $(45,46)$. Tissue analysis $(47,48,49)$ shows scattered brown adipocytes in omental white fat, strongly suggesting that sustained catecholamine stimulation can induce the browning of WAT in humans.

Noradrenaline regulates brown adipocyte function via beta adrenergic receptors ( $\beta$-AR) (50). Activation of $\beta$-AR triggers a cascade of intracellular changes via the cyclic AMP-phosphokinase A signalling pathway $(1,50)$. These include transcriptional activation and expression of the UCP1 gene (50), increased glucose uptake (51) and lipolysis (1), resulting in increase in thermogenic capacity and substrate availability of the tissue.

There are three types of $\beta$-ARs $\left(\beta_{1}, \beta_{2}\right.$ and $\left.\beta_{3}\right)$, all of which are expressed in BAT $(52,53,54,55) . \beta_{3}$ is the predominant $\beta$-AR in BAT of rodents $(54,55)$. In contrast, $\beta_{1}$ and $\beta_{2}$ are more abundant than $\beta_{3}$ in human brown adipocytes $(52,53)$. Propranolol, a beta-blocker with predominant action on $\beta_{1}$ and $\beta_{2}$ and poor efficacy for $\beta_{3}$, abolishes BAT activity seen on FDG-PET scan in humans $(56,57)$. This observation suggests that $\beta_{1}$ and $\beta_{2}$ receptors are more important than $\beta_{3}$ in regulating human BAT activity. However, a recent study found that human BAT activity can be stimulated by a $\beta_{3}$-AR-agonist (mirabegron) at high dose (58). Mirabegron caused significant cardiovascular effects (58), indicating that the effects observed may not be $\beta_{3}$ exclusive, and may in part be $\beta_{1}$-AR mediated. Further work is needed to understand the action of each beta-adrenergic receptor subtype in regulating BAT in humans.

Thyroid hormone - Thyroid hormone plays an important role in the regulation of thermogenesis (59). Thyroid hormone regulates BAT function via peripheral and central mechanisms. Type 2 deiodinase (DiO2), which converts $\mathrm{T}_{4}$ to bioactive $\mathrm{T}_{3}$, is highly expressed in BAT (4). The resultant $\mathrm{T}_{3}$ directly stimulates UCP1 expression and mitochondrial biogenesis in human adipocytes in vitro (60). Rodent studies reveal that $\mathrm{T}_{3}$ also interacts synergistically with the SNS, by upregulating $\beta$-AR expression (61) and noradrenaline signalling (62). Moreover, $\mathrm{T}_{3}$ acts centrally on the hypothalamus. Intracerebral administration of $\mathrm{T}_{3}$ causes marked stimulation of BAT function, causing weight loss in rats (63).

Thyroid hormone also stimulates BAT activity in humans in vivo. BAT FDG uptake in a hypothyroid subject increased with thyroid hormone replacement and fell on its withdrawal (64). Lahesmaa et al. (65) reported a threefold higher BAT activity by FDG-PET-CT in hyperthyroid patients than in healthy subjects and that BAT activity decreased after treatment of hyperthyroidism.

There is evidence that thyroid hormone also induces the browning of WAT in humans. Brown adipocyte-like cells with increased UCP1 expression were found within the periumbilical WAT after therapy with a supraphysiological dose of thyroid hormone (64).

Effects of thyroid hormone are mediated by thyroid hormone receptors (TR). There are two isoforms of TR, TR $\alpha$ and TR $\beta$, with different tissue distributions. The cardiac effects of thyroid hormone are predominantly mediated via $\operatorname{TR} \alpha$ while its metabolic effects are mediated via $\operatorname{TR} \beta$ (66). In rodent brown adipocytes, the binding of thyroid hormone to TR $\beta$ upregulates UCP1 expression $(67,68)$. A TR $\beta$-agonist, GC-1, enhances BAT UCP1 content (68), increases metabolic rate, reduces body weight and lowers serum cholesterol level (69) without cardiac adverse effects (70) in animals. If these findings are replicable in humans, selective activation of TR $\beta$ may be a promising therapeutic strategy to exploit the beneficial metabolic effects of thyroid hormone while avoiding the detrimental cardiac side effects. 
Glucocorticoids - Glucocorticoid excess causes obesity, typically observed in patients with Cushing's syndrome (71). The mechanisms by which glucocorticoids induce adiposity are not well understood but are likely multifactorial. Glucocorticoids enhance the recruitment of preadipocytes to mature white adipocytes and interact with other hormones such as insulin to activate a program of white adipocyte differentiation (72). Glucocorticoids also stimulate appetite centrally (73). The possibility that suppression of BAT function may mediate in part the weight gain induced by glucocorticoids has received little attention in humans.

BAT contains high affinity glucocorticoid receptors (74). Rodent studies show that glucocorticoids inhibit the expression of UCP1 $(75,76)$. Glucocorticoids also down regulate $\beta$-adrenergic receptors $(77,78)$, reducing tissue responsiveness to adrenergic and cold stimulation $(76,79)$. Pharmacological inhibition of glucocorticoid action by mifepristone, a glucocorticoid receptor antagonist, activates BAT and reduces body weight gain without change in food intake (80). This observation suggests that the lesser gain in body weight arose from stimulation of energy expenditure. Collectively, these animal data provide strong evidence that glucocorticoids cause weight gain by suppressing BAT activity.

Evidence for a regulatory role of glucocorticoids in human BAT is sparse. Using primary brown preadipocytes derived from supraclavicular fat biopsies, Barclay et al. (81) observed that glucocorticoids stimulated the proliferation and differentiation of the cells into mature brown adipocytes, but attenuated the adrenergic-stimulation of brown adipocytes function. These in vitro observations indicate that glucocorticoids exert complex effects on development and function of brown adipocytes in humans and that BAT is involved in mediating the obesogenic consequences of glucocorticoid excess. The in vivo effect of glucocorticoids on BAT activity in humans has not yet been reported.

Mineralocorticoid $\bullet$ Mineralocorticoid receptors (MCRs) are expressed in many tissues including adipose tissue (82). The prevalence of metabolic syndrome is increased in primary aldosteronism $(83,84)$, and correction of mineralocorticoid excess in subjects with primary hyperaldosteronism improves the metabolic abnormality (85), suggesting that mineralocorticoid system may play a role in metabolic regulation.

Rodent studies have provided evidence that aldosterone affects BAT function $(86,87)$. Aldosterone inhibits the expression and function of UCP1 in a rodent brown adipose cell line $(87,88)$. MCR antagonists such as spironolactone and drospirenone induce the emergence of brown adipocyte-like cells within the white adipose tissue, improve glucose tolerance and prevent weight gain in mice fed a high-fat diet (89). These observations provide evidence that mineralocorticoid system regulates BAT in rodents. It is unknown whether mineralocorticoid system exerts a similar effect on BAT in humans.

Sex hormones $~-$ Sex hormones regulate body fat mass (90). Brown adipocytes from male and female rats express sex steroid receptors (91). Animal studies provide some evidence that oestrogen and androgen regulate BAT function. Ovariectomy causes atrophy of BAT depots, an effect reversed by oestrogen replacement (92), indicating that oestrogen promotes BAT mass. The effect of testosterone on BAT is less clear. Some studies have observed negative effect $(93,94)$ while others have reported positive (95) or no apparent effect (96).

Role of sex hormones in the control of human BAT is suggested by the observation of gender dimorphism in the prevalence of BAT in several retrospective analyses of the scans taken under ambient conditions $(25,27,97,98)$. Women exhibit approximately two to threefold higher prevalence of BAT than men $(97,98)$. Women also have a higher level of BAT FDG uptake activity and a greater BAT volume than men $(27,97)$. This striking gender dimorphism may suggest that oestrogen stimulates while androgen suppresses BAT function in humans. However, a gender difference has not been observed in prospective studies employing cold stimulation of subjects $(3,29,99)$, suggesting that a difference in sensitivity to environmental temperature might explain the gender difference observed in the retrospective studies. Studies investigating the specific effects of oestrogen and androgen on BAT activity in humans have not yet been reported.

Insulin $~$ Another candidate regulating BAT is insulin. The role of insulin in the regulation of BAT is complex. The effect seems to be time-dependent. This is supported by the findings from studies of animals rendered insulin depleted by streptozocin treatment. BAT thermogenic response was unaffected acutely but reduced significantly after 7 days of insulin depletion, in parallel with a progressive decline in the tissue weight and the protein content (100). Replacement of insulin restored BAT function and mass over a few days (100, 101, 102). These findings suggest that insulin has a role in maintaining BAT mass and function over time. 
Insulin regulates BAT via a direct action on brown adipocytes as well as indirectly via the SNS. Insulin stimulates BAT glucose uptake and lipogenesis in isolated brown adipocytes $(103,104)$. In rodents, BAT is lost when the insulin receptor is knocked out, suggesting that insulin regulates BAT growth (105).

The regulation of UCP1 expression and thermogenic function in BAT by insulin seems to be mediated via its augmentation of the SNS $(106,107)$. In streptozocintreated diabetic mice, insulin replacement restores UCP1 content of BAT with intact SNS. However, denervation of SNS to BAT prevents the restoration of the UCP1 content by insulin (108), indicating that the regulation of UCP1 and BAT thermogenic function by insulin requires sympathoactivation.

In humans, Orava et al. (35) have investigated the regulatory role of insulin using the hyperinsulinaemic euglycaemic clamp in a warm environment to minimise the contributing effect of the SNS. Under these conditions, insulin enhanced FDG uptake in BAT by fivefold, an extent similar to that in skeletal muscle. However, the increase in glucose uptake was not accompanied by an increase in thermogenesis nor blood flow to the BAT (35). These findings, in agreement with those from the animal studies, demonstrated that insulin, by itself, increased glucose uptake in BAT without stimulating its thermogenic function. Taken together, it is likely that insulin plays a permissive role in the regulation of BAT mass and function by SNS, especially in the long term.

Dietary factors $~$ Food intake induces thermogenesis (109). The caloric content of a meal correlates with the thermogenic response (110). The response also varies with the type of nutrient ingested; dietary protein induces higher thermogenic response than fat or carbohydrate (111).

BAT has been proposed to mediate the thermic effect of food. This is based on the findings from animal studies that prolonged overfeeding results in BAT hyperplasia $(112,113)$ while caloric restriction reduces BAT mass and function (114). Although the issue as to whether BAT contributes to diet-induced thermogenesis is controversial (115), there is evidence suggesting that some dietary supplements exert thermic effects through BAT in humans.

Capsaicin is a component of chilli peppers which stimulates thermogenesis and reduces body fat in both animals (116) and humans $(117,118)$. Capsaicin stimulates BAT thermogenesis via indirect and direct mechanisms involving vanilloid subtype 1 of transient receptor potential (TRPV1) receptors (119). The indirect effect is mediated by TRPV1 receptors in the gastrointestinal tract. Activation of gastrointestinal TRPV1 receptors by capsaicin increases central sympathetic stimulation of BAT (120). Capsaicin also acts directly on TRPV1 receptors in adipose tissue (121), increasing expression of brown adipocytes marker genes in differentiating 3T3-L1 preadipocytes in vitro (122).

Capsinoids are non-pungent counterparts of capsaicin possessing effects similar to capsaicin on energy metabolism, but without the pungent taste $(123,124)$. The involvement of human BAT in the thermic effect of these compounds was reported by Yoneshiro et al. (125). Capsinoids acutely increased resting energy expenditure significantly only in BAT-positive subjects but not in BAT-negative subjects (125). Another dietary ingredient sharing a similar structure to capsaicin is grains of paradise (GP), also known as guinea pepper or alligator pepper. Sugita et al. (126) showed that a single oral ingestion of GP extract stimulated energy expenditure in BAT-positive subjects while no effect was observed in BAT-negative subjects. These findings suggest that the thermogenic effects induced by capsinoids and GP are mediated by BAT.

Rodent studies have provided some evidences that the thermogenic response to a meal involves the activation of BAT $(112,113)$. The question as to whether meal-induced thermogenesis in humans is also mediated by BAT was investigated by Vosselman et al. (41) by comparing FDG uptake after a standardised meal to that observed under cool stimulation during the fasted state. They found that BAT activity after a meal was less than that observed during cool stimulation. They also observed greater FDG uptake into muscle after a meal than during cool stimulation (41). Vrieze et al. (127) addressed the same question by comparing BAT activity 90 min after a meal to that after an overnight fast. They observed that FDG uptake was significantly lower during the meal study. The results from both these studies are problematic and difficult to interpret because of the competing effects of meal-derived glucose with FDG uptake into BAT and the confounding stimulatory effects of variable concentrations of insulin on glucose uptake into tissues. Thus, evidence for a role of BAT in mediating diet-induced thermogenesis is not established in humans.

Exercise and irisin $~-$ The notion that exercise can induce the browning of WAT emerged after the discovery of a myokine termed irisin. Irisin is a peptide cleaved from fibronectin type III domain containing protein 5 (FNDC5), released by the exercising muscle, and mediates browning of WAT in mice (128). In mice, 3 weeks of exercise 
increased UCP1 mRNA level in subcutaneous inguinal fat depot by more than 20-fold, and led to a twofold rise in plasma irisin level. Intravenous administration of irisinexpressing adenoviral particles also replicated a browning effect, causing a significant reduction in body weight and an improvement in glucose tolerance (128). These findings suggest that the metabolic effects of exercise may have been mediated by irisin through the browning of adipose tissue.

In humans, the evidence supporting an effect of exercise on irisin and adipose tissue browning is inconclusive. Some studies have observed an acute increase in plasma irisin level after exercise $(40,129,130,131)$ whereas others have not $(132,133)$. With regards to chronic exercise, Bostrom et al. (128) reported a twofold rise in plasma irisin level after 10 weeks of endurance training (128) while Norheim et al. (131) found an opposite effect after 12 weeks of combined endurance and strength training. In a randomised controlled trial of 26 weeks evaluating the effect of two training programs (aerobic endurance and strength endurance training) on serum irisin level, Hecksteden et al. (134) observed no significant effect of either of the exercise regimens. Huh et al. (129) and Pekkala et al. (133) also found no effect of long-term training on irisin level. Browning of WAT has not been observed after irisin/FNDC5 treatment in vitro $(40,135)$ in humans. A study investigating the effect of FNDC5 treatment on human adipose cells found that UCP1 mRNA expression increased predominantly in classical brown adipocytes rather than white adipocytes (40).

The discrepancies in the findings may arise from methodological differences in the exercise regimens, timing of blood collection and assays used for measuring irisin. In summary, the effect of exercise on irisin and brown fat genes program remains to be substantiated in humans.

Others $~$ Several peptides have recently been identified as promoters of browning in humans: fibroblast growth factor-21 (FGF21), bone morphogenic proteins (BMPs) and cardiac natriuretic peptides (ANP and BNP).

FGF21, a member of FGF family, is produced mainly by the liver but is also expressed in adipocytes, skeletal muscle and pancreas. It is a regulator of substrate metabolism and body weight in animals (136). Systemic administration of FGF21 to obese mice lowers blood glucose level, enhances fatty acid oxidation and increases energy expenditure, leading to weight loss $(136,137,138)$. Recently, Lee et al. (139) reported that human BAT is a source of FGF21. FGF21 was secreted by brown adipocytes from human neck fat and promoted a BAT thermogenic program in white adipocytes (139). This group also showed in healthy subjects that cold exposure increased plasma FGF21, the levels of which correlated with the thermogenic responses (140). These results suggest that FGF21 may be a mediator of WAT browning induced by cold. These findings are supported by a study in mice in which genetic ablation of FGF21 attenuated the molecular and morphological features of browning induced by cold stimulation (141).

BMPs belong to the transforming growth factor beta (TGF $\beta$ ) superfamily which is involved in the formation of mesenchymal cells (142). BMP4, BMP7 and BMP6 induce the development of brite and brown adipocytes from human primary adipose stem cells (143) and from skeletal muscle precursor cells (144) respectively. Interestingly, the findings from Elsen et al. study (143) also suggested that BMP4 is an adipokine secreted by the adipose stem cells, acting as an autocrine regulator of brown adipogenesis.

Natriuretic peptides play a role in food intake and energy expenditure in mice (145). A possible regulatory role of ANP and BNP in human brown fat was investigated by Bordicchia et al. (146) using differentiated human multipotent adipose-derived stem cells culture, the authors found that the peptides induced the expression of brown fat genes, which was accompanied by an increase in oxygen consumption, an effect potentiated by $\beta$-agonists.

These findings highlight the complex interactions between BAT and several systems, regulating energy homeostasis.

\section{Metabolic significance of BAT in humans}

While it is well established that BAT contributes significantly to energy balance in animals (147, 148, 149), evidence that BAT is metabolically significant in humans has only emerged recently.

\section{BAT and adiposity}

Observational studies - Several large observational studies have reported that active BAT is more frequently detected in lean than in obese individuals $(28,97,98,150$, 151). BAT mass and activity negatively correlates with BMI (27). These studies are limited in being retrospective, with results drawn from scans performed under non-standardised ambient conditions. Subsequent prospective studies have however confirmed a negative relationship between the BAT activity and adiposity under standardised scanning conditions $(3,29,99,152)$ (Fig. 1). Some studies 


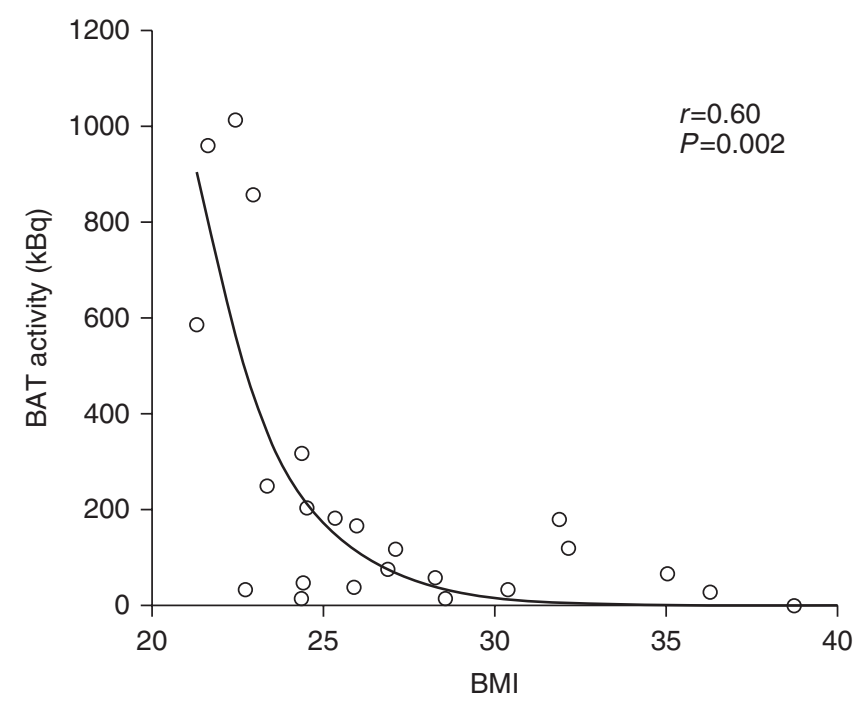

Figure 1

Relationship between BMI and BAT activity measured on FDG-PET-CT scans after acute cold exposure (Reproduced with permission from van Marken Lichtenbelt WD, Vanhommerig JW, Smulders NM, Drossaerts JM, Kemerink GJ, Bouvy ND, Schrauwen $P$ \& Teule GJ. Cold-activated brown adipose tissue in healthy men. New England Journal of Medicine 2009360 1500-1508).

have employed a precooling protocol aimed at enhancing BAT function maximally without inducing shiver $(3,99)$. These observations suggest that impaired BAT function may predispose to obesity in humans. However, cause and effect cannot be determined from association studies.

Interventional studies $\bullet$ Several groups have addressed the metabolic significance of BAT in adult humans by determining i) whether resting energy expenditure is increased when BAT is activated $(33,34,35,38,39,153)$, ii) whether prolonged BAT activation results in a loss of body fat that is related to the degree of BAT activation (24). BAT 'positive' subjects show a greater increase in resting EE during cold stimulation than BAT 'negative' subjects. The increment in energy expenditure from cold stimulation is termed cold-induced thermogenesis (CIT). CIT correlates with BAT activity (153). The differences in CIT between BAT-positive and BAT-negative subjects ranged from 120 to $368 \mathrm{kcal}$ per day. Table 1 summarises the studies reporting the contribution of BAT to energy expenditure in humans on cold stimulation.

It is estimated that on average, $\sim 50 \mathrm{~g}$ of BAT is present in adult humans and, when continually activated, contributes $\sim 170$ kcal to daily energy expenditure $(34,35)$. Energy deficit of $500 \mathrm{kcal}$ per day equates to $0.4 \mathrm{~kg}$ of fat loss per week, based on the energy density of fat ( $9 \mathrm{kcal}$ per $1 \mathrm{~g}$ ). Therefore, an increase in energy expenditure of $170 \mathrm{kcal}$ per day from continuous activation of BAT translates into $\sim 7 \mathrm{~kg}$ of fat loss in 1 year, assuming no change in energy intake. However, given the complex feedback mechanisms of energy metabolism and the lack of a realistic way for constantly stimulating BAT, caution should be exercised in extrapolating the extent of clinical benefit.

The evidence that activating BAT can indeed control body fat comes from a study in which subjects with low or undetectable BAT activity at baseline were randomly assigned to undergo 6 weeks of intermittent cold exposure at $17^{\circ} \mathrm{C}$ for $2 \mathrm{~h}$ daily or to continue their usual daily living (24). Those assigned to the cold intervention lost $0.7 \mathrm{~kg}$ of mean body fat in 6 weeks in parallel with an $\sim 1.5$-fold increase in BAT activity whereas those who continued with usual daily living had no change in BAT activity or body fat (Fig. 2) (24).

Taken together, these controlled interventional studies provide unequivocal evidence that BAT in human is metabolically significant.

Table 1 Summary of studies reporting detected amount of BAT and associated CIT after acute cold stimulation in adult humans.

\begin{tabular}{|c|c|c|}
\hline References & Number of subjects & Cooling temperature $\left({ }^{\circ} \mathrm{C}\right)$ \\
\hline (33) & 6 & 18 \\
\hline (34) & $\begin{array}{l}9 \text { with high BAT } \\
15 \text { with low BAT }\end{array}$ & 15 \\
\hline (35) & $\begin{array}{l}19 \text { BAT positive } \\
8 \text { BAT negative }\end{array}$ & $17 \pm 1$ \\
\hline (38) & 24 & 19 \\
\hline (39) & 10 & 14 \\
\hline (153) & $\begin{array}{l}6 \text { BAT positive } \\
7 \text { BAT negative }\end{array}$ & 19 \\
\hline
\end{tabular}

\begin{tabular}{|c|c|}
\hline BAT amount & CIT (kcal/day) \\
\hline $\begin{array}{l}\text { Mean } 168 \mathrm{ml} \\
\text { Mean } 59.1 \mathrm{~g} \\
\text { Mean } 2.2 \mathrm{~g} \\
\text { Mean } 34 \mathrm{~g}\end{array}$ & $\begin{array}{l}\text { Mean } 2000 \\
\text { Mean } 237 \\
\text { Mean } 39 \\
\text { Mean } 287^{a} \\
\text { Mean } 167^{a}\end{array}$ \\
\hline $\begin{array}{l}\text { Mean } 63 \mathrm{ml} \\
\text { Median } 15 \mathrm{ml} \\
\text { No data }\end{array}$ & $\begin{array}{l}\text { Mean } 88 \\
\text { Mean } 79 \\
\text { Mean } 410 \\
\text { Mean } 42\end{array}$ \\
\hline
\end{tabular}

${ }^{\mathrm{a} C o n v e r t e d ~ f r o m ~ M e g a j o u l e ~ u s i n g ~} 1 \mathrm{MJ}=239 \mathrm{kcal}$, normalised for fat free mass. 

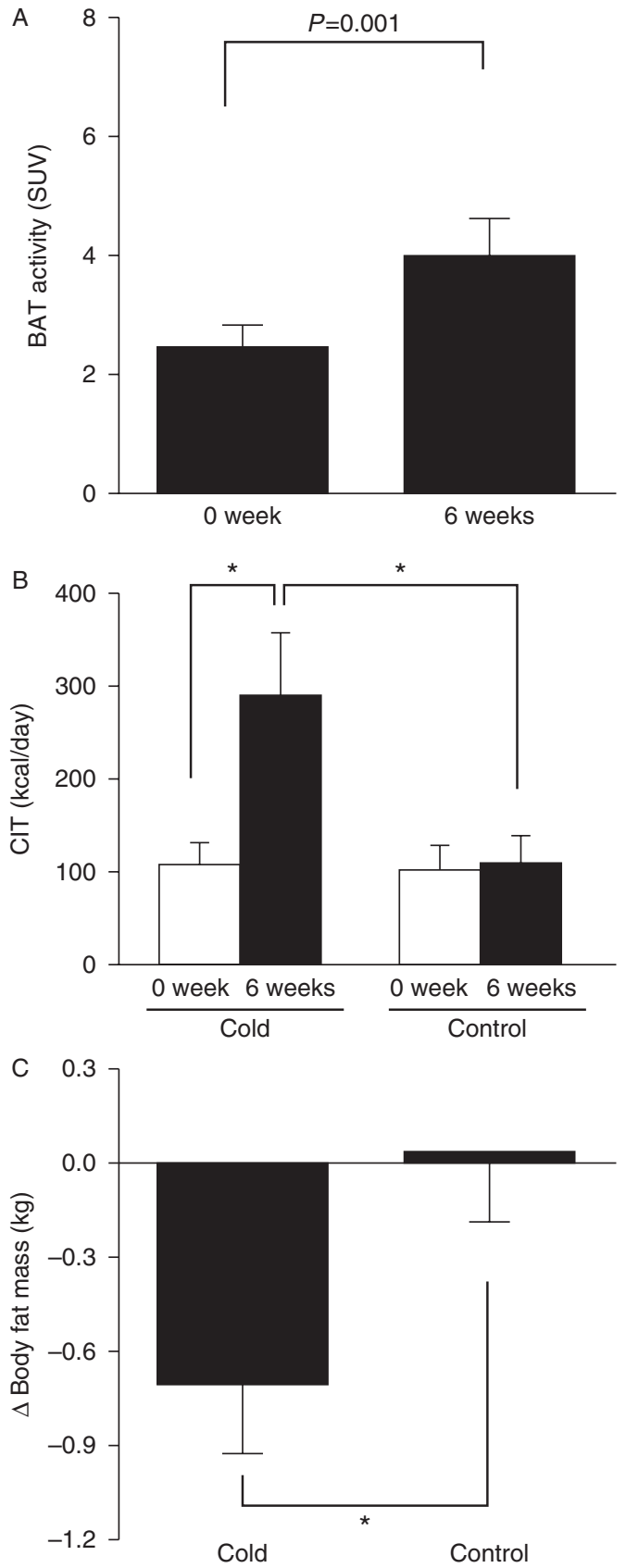

\section{Figure 2}

Effect of chronic cold exposure on BAT activity, CIT and body fat mass in humans. (A) BAT activity plotted in standardised uptake value (SUV), measured on FDG-PET-CT scans before and after 6 weeks of daily cold exposure. (B) CIT expressed in kcal/day in subjects who underwent the cold intervention (cold group) and those who continued their usual daily living (control group). (C) Change in body fat mass from baseline after 6 weeks in the cold group and control group. Expressed in mean \pm s.E.M.; $* P<0.05$ (Adapted with permission from (24)).

\section{BAT and substrate metabolism}

BAT utilises free fatty acids and glucose as metabolic fuels (1). It is therefore conceivable that activated BAT may induce beneficial changes in metabolic profile, by reducing blood triglyceride and glucose levels. In rodents, chronic BAT activation by cold-acclimatisation markedly reduces circulating triglyceride and glucose concentrations (154). Compared to rodents, the amount of BAT corrected for body mass is much lower in humans and the absolute ability of BAT to clear metabolic substrates from the circulation could be less in humans.

In humans, cross-sectional studies have reported that blood glucose levels of BAT-positive subjects are significantly lower than that of BAT-negative individuals (28, $29,97,98)$. The metabolic significance cannot be deduced from these studies because it is not clear whether the glucose difference is a cause or consequence of reduced BAT activity.

Convincing evidence that activation of BAT in humans can improve the metabolic status comes from recent longitudinal studies reporting improvements in glucose metabolism in subjects undergoing intermittent cold stimulation $(21,22,37)$. The participants underwent a few hours of cooling daily for varying periods (10 days (37)-1 month $(21,22)$ ). Stimulation of BAT function by cold over time was associated with a significant fall in circulating glucose (21) and improvements in insulin sensitivity $(22,37)$. Table 2 summarises the studies addressing the role of BAT in adiposity and substrate metabolism in humans. Interestingly, one study (37) found enhanced skeletal muscle GLUT4 translocation after cold acclimatisation and attributed the improvement in glucose metabolism mainly to the skeletal muscle glucose uptake. However, parallel tissue analysis was not performed in BAT. The intensity of FDG uptake in the cold-acclimatised BAT was comparable to that in skeletal muscle on PET scan (37), indicating that BAT also contributed to the glucose clearance (Fig. 3). Moreover, another study (22) reported no change in skeletal muscle GLUT4 expression after cold acclimatisation. Orava et al. (35) have also showed that the avidity of glucose uptake in BAT during cold stimulation in humans is comparable with that of insulin-stimulated skeletal muscle. Thus, on balance, the evidence supports a significant and beneficial role of BAT in glucose metabolism.

\section{Future perspectives}

An understanding of the physiology of BAT in humans is evolving. Development of therapeutic approaches to 
Table 2 Summary of cold acclimatisation studies addressing the role of BAT in adiposity and substrate metabolism in humans.

\begin{tabular}{|c|c|c|}
\hline References & Number of subjects & $\begin{array}{l}\text { Acclimatisation } \\
\text { protocol }\end{array}$ \\
\hline$(24)$ & $\begin{array}{l}22 \text { randomised to cold } \\
\text { intervention or usual } \\
\text { living (control) }\end{array}$ & $17^{\circ} \mathrm{C}, 2 \mathrm{~h} /$ day for 6 weeks \\
\hline$(21)$ & 6 & $10^{\circ} \mathrm{C}, 2 \mathrm{~h} /$ day for 4 weeks \\
\hline$(22)$ & 5 & $19^{\circ} \mathrm{C}$ overnight for 1 month \\
\hline (37) & 10 & $14-15^{\circ} \mathrm{C}$ for 10 days \\
\hline
\end{tabular}

\begin{tabular}{l}
$\triangle B A T$ activity from \\
baseline \\
\hline $58 \%$ increase (no \\
significant change \\
in the control group) \\
$45 \%$ increase \\
$54 \%$ increase \\
$\sim 50 \%$ increase
\end{tabular}

$\Delta$ Metabolism from baseline

$5.2 \%$ or $0.7 \mathrm{~kg}$ decrease in body fat mass (no significant change in the control group) $6.2 \%$ decrease in plasma glucose $>50 \%$ increase in insulin sensitivity $43 \%$ increase in insulin sensitivity harness BAT will require a comprehensive appreciation of the pathways regulating BAT function and mass and of the implication of altered BAT function and mass on energy metabolism in humans.

Cold exposure, despite being a powerful promoter of BAT mass and function, resulting in metabolic benefits, is unlikely to be widely adopted by individuals at the expense of personal comfort. However, controlling indoor temperature of buildings to allow a modest cooling of occupants is a realistic and acceptable public health measure at a population level to help tackle the obesity pandemic. Studies on its effectiveness are warranted.

An alternative way to mimic the stimulatory effect of cold is activation of the sympathetic $\beta$-adrenergic system. The results of studies using non-specific sympathomimetics to activate human BAT $(155,156)$ so far have not been promising with only one study showing BATenhancing effect using high dose ephedrine (157). This likely reflects the dose limitation of nonspecific sympathomimetics from adverse cardiac effects. The positive result from a recent study of a $\beta_{3}$-selective agonist, mirabegron (58), brings some hope for possible pharmacological activation of BAT although the drug appears to induce cardiovascular side effects with the dose used. The potential of more highly selective $\beta$-adrenergics devoid of $\beta_{1}$ cardiac risks merits further exploration. One such agent is formoterol. Formoterol is a long-acting, potent, highly selective $\beta_{2}$-agonist, approved for treatment of bronchial asthma and obstructive airway diseases. In an open label study of healthy individuals, oral formoterol stimulated fat oxidation and augmented resting energy expenditure by $15 \%$ without inducing tachycardia in therapeutic doses (158). These metabolic changes imparted by formoterol are similar to the changes expected from the activation of BAT, suggesting that formoterol may be BAT-activating.

The discovery of other novel, non-adrenergic pathways such as FGF21 and irisin and thyroid hormone analogue is exciting. It remains to be tested whether this could lead to new therapeutic utility in humans.
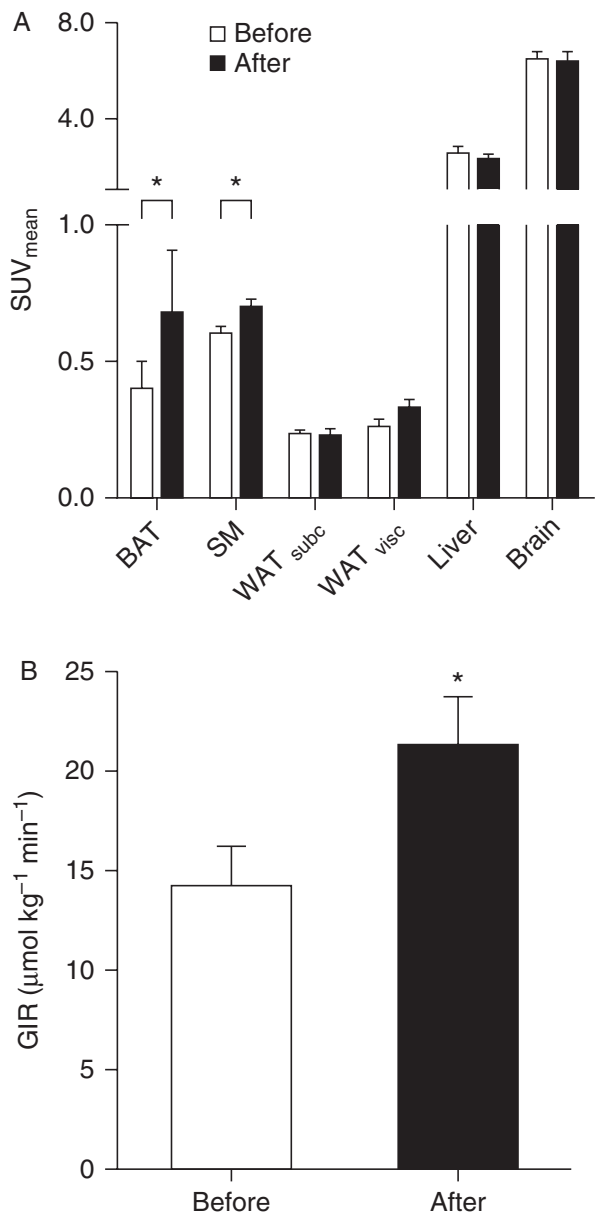

\section{Figure 3}

Effect of cold acclimatisation on FDG uptake in BAT and insulin sensitivity in humans. (A) FDG uptakes expressed as SUV mean, $_{\text {, }}$ measured in the supraclavicular BAT, upper-body skeletal muscle

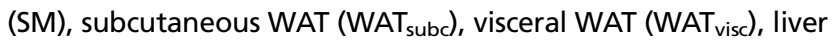
and brain on FDG-PET-CT scans taken before and after 10 days of cold acclimatisation. (B) Glucose infusion rate (GIR), corrected for body weight, during hyperinsulinemic euglycaemic clamp, before and after the cold intervention. Expressed in mean \pm s.E.M. $\star P<0.05$ (Adapted with permission from (37)). 
In addition to its role in protection against cold, BAT also protects against diet-induced obesity in small mammals through mediation of the thermic effect of food $(147,148,149)$. Whether this is true in humans is not yet established, but the findings of the studies using capsinoids $(125,126)$ support the contribution of BAT to the thermogenic effect of food supplements. Macronutrients differ in their thermogenic potential (111), and whether this is explained by differences in BAT activation awaits further investigation.

Finally, it is desirable to develop non-invasive techniques that can distinguish changes in BAT function from mass. This is important for developing therapeutic strategies; for instance, agents that affect only BAT mass should be complemented by those that activate BAT function, in order to achieve optimal therapeutic benefits. Currently, non-invasive assessment of BAT function is confined to PET-CT scan. In addition to the radiation safety constraints, FDG-PET-CT cannot provide information on BAT function during meal studies. Preliminary results on the use of thermal imaging (infrared thermography, IRT) in detecting BAT activity in humans are promising. IRT detects a higher temperature on the skin overlying BAT in the supraclavicular region compared with the skin overlying other area $(159,160,161)$. This calls for further study to develop the use of IRT in assessing changes in BAT activity.

With regards to quantifying BAT mass, a few encouraging reports on the application of magnetic resonance imaging have emerged, albeit in a small number of adult humans $(162,163)$. The technique is based on the notion that BAT and WAT display different water-to-fat ratios or signal intensities, with the BAT having a higher waterto-fat ratio $(162,163)$. More research is warranted to verify its reliability and reproducibility.

\section{Conclusion}

Research in the past few years have substantiated the concept that BAT in adult humans is regulated by multiple mechanisms and is metabolically significant. This has given insights into its physiology in humans providing the basis for exploiting its thermogenic capacity in management of obesity and metabolic diseases.

\section{Declaration of interest}

The authors declare that there is no conflict of interest that could be perceived as prejudicing the impartiality of the review.
Funding

M Thuzar is supported by a Research Fellowship from the Princess Alexandra Hospital Research Support Scheme.

\section{References}

1 Cannon B \& Nedergaard J. Brown adipose tissue: function and physiological significance. Physiological Reviews 200484 277-359. (doi:10.1152/physrev.00015.2003)

2 Lee P, Zhao JT, Swarbrick MM, Gracie G, Bova R, Greenfield JR, Freund J \& Ho KK. High prevalence of brown adipose tissue in adult humans. Journal of Clinical Endocrinology and Metabolism 201196 2450-2455. (doi:10.1210/jc.2011-0487)

3 van Marken Lichtenbelt WD, Vanhommerig JW, Smulders NM, Drossaerts JM, Kemerink GJ, Bouvy ND, Schrauwen P \& Teule GJ. Cold-activated brown adipose tissue in healthy men. New England Journal of Medicine 2009360 1500-1508. (doi:10.1056/ NEJMoa0808718)

4 Virtanen KA, Lidell ME, Orava J, Heglind M, Westergren R, Niemi T, Taittonen M, Laine J, Savisto NJ, Enerback S et al. Functional brown adipose tissue in healthy adults. New England Journal of Medicine 2009 360 1518-1525. (doi:10.1056/NEJMoa0808949)

5 Zingaretti MC, Crosta F, Vitali A, Guerrieri M, Frontini A, Cannon B, Nedergaard J \& Cinti S. The presence of UCP1 demonstrates that metabolically active adipose tissue in the neck of adult humans truly represents brown adipose tissue. FASEB Journal 200923 3113-3120. (doi:10.1096/fj.09-133546)

6 Petrovic N, Walden TB, Shabalina IG, Timmons JA, Cannon B \& Nedergaard J. Chronic peroxisome proliferator-activated receptor $\gamma$ $(\mathrm{PPAR} \gamma)$ activation of epididymally derived white adipocyte cultures reveals a population of thermogenically competent, UCP1-containing adipocytes molecularly distinct from classic brown adipocytes. Journal of Biological Chemistry 2010285 7153-7164. (doi:10.1074/jbc. M109.053942)

7 Seale P, Bjork B, Yang W, Kajimura S, Chin S, Kuang S, Scime A, Devarakonda S, Conroe HM, Erdjument-Bromage H et al. PRDM16 controls a brown fat/skeletal muscle switch. Nature $2008 \mathbf{4 5 4}$ 961-967. (doi:10.1038/nature07182)

8 Wu J, Bostrom P, Sparks LM, Ye L, Choi JH, Giang AH, Khandekar M, Virtanen KA, Nuutila P, Schaart G et al. Beige adipocytes are a distinct type of thermogenic fat cell in mouse and human. Cell $2012 \mathbf{1 5 0}$ 366-376. (doi:10.1016/j.cell.2012.05.016)

9 Timmons JA, Wennmalm K, Larsson O, Walden TB, Lassmann T, Petrovic N, Hamilton DL, Gimeno RE, Wahlestedt C, Baar K et al. Myogenic gene expression signature establishes that brown and white adipocytes originate from distinct cell lineages. PNAS $2007 \mathbf{1 0 4}$ 4401-4406. (doi:10.1073/pnas.0610615104)

10 Barbatelli G, Murano I, Madsen L, Hao Q, Jimenez M, Kristiansen K, Giacobino JP, De Matteis R \& Cinti S. The emergence of cold-induced brown adipocytes in mouse white fat depots is determined predominantly by white to brown adipocyte transdifferentiation. American Journal of Physiology. Endocrinology and Metabolism 2010298 E1244-E1253. (doi:10.1152/ajpendo.00600.2009)

11 Young P, Arch JR \& Ashwell M. Brown adipose tissue in the parametrial fat pad of the mouse. FEBS Letters 1984167 10-14. (doi:10.1016/0014-5793(84)80822-4)

12 Walden TB, Hansen IR, Timmons JA, Cannon B \& Nedergaard J. Recruited vs. nonrecruited molecular signatures of brown, "brite," and white adipose tissues. American Journal of Physiology. Endocrinology and Metabolism 2012302 E19-E31. (doi:10.1152/ajpendo.00249.2011)

13 Cypess AM, White AP, Vernochet C, Schulz TJ, Xue R, Sass CA, Huang TL, Roberts-Toler C, Weiner LS, Sze C et al. Anatomical localization, gene expression profiling and functional characterization 
of adult human neck brown fat. Nature Medicine 201319 635-639. (doi:10.1038/nm.3112)

14 Lidell ME, Betz MJ, Dahlqvist Leinhard O, Heglind M, Elander L, Slawik M, Mussack T, Nilsson D, Romu T, Nuutila P et al. Evidence for two types of brown adipose tissue in humans. Nature Medicine 201319 631-634. (doi:10.1038/nm.3017)

15 Jespersen NZ, Larsen TJ, Peijs L, Daugaard S, Homoe P, Loft A, de Jong J, Mathur N, Cannon B, Nedergaard J et al. A classical brown adipose tissue mRNA signature partly overlaps with brite in the supraclavicular region of adult humans. Cell Metabolism $2013 \mathbf{1 7}$ 798-805. (doi:10.1016/j.cmet.2013.04.011)

16 Himms-Hagen J, Melnyk A, Zingaretti MC, Ceresi E, Barbatelli G \& Cinti S. Multilocular fat cells in WAT of CL-316243-treated rats derive directly from white adipocytes. American Journal of Physiology. Cell Physiology 2000279 C670-C681.

17 Lee YH, Petkova AP, Mottillo EP \& Granneman JG. In vivo identification of bipotential adipocyte progenitors recruited by $\beta 3$-adrenoceptor activation and high-fat feeding. Cell Metabolism 2012 15 480-491. (doi:10.1016/j.cmet.2012.03.009)

18 Wang QA, Tao C, Gupta RK \& Scherer PE. Tracking adipogenesis during white adipose tissue development, expansion and regeneration. Nature Medicine 201319 1338-1344. (doi:10.1038/nm.3324)

19 Bukowiecki L, Collet AJ, Follea N, Guay G \& Jahjah L. Brown adipose tissue hyperplasia: a fundamental mechanism of adaptation to cold and hyperphagia. American Journal of Physiology 1982242 E353-E359.

20 Bukowiecki LJ, Geloen A \& Collet AJ. Proliferation and differentiation of brown adipocytes from interstitial cells during cold acclimation. American Journal of Physiology 1986250 C880-C887.

21 Blondin DP, Labbe SM, Tingelstad HC, Noll C, Kunach M, Phoenix S, Guerin B, Turcotte EE, Carpentier AC, Richard D et al. Increased brown adipose tissue oxidative capacity in cold-acclimated humans. Journal of Clinical Endocrinology and Metabolism 201499 E438-E446. (doi:10.1210/jc.2013-3901)

22 Lee P, Smith S, Linderman J, Courville AB, Brychta RJ, Dieckmann W, Werner CD, Chen KY \& Celi FS. Temperature-acclimated brown adipose tissue modulates insulin sensitivity in humans. Diabetes 2014 63 3686-3698. (doi:10.2337/db14-0513)

23 van der Lans AA, Hoeks J, Brans B, Vijgen GH, Visser MG, Vosselman MJ, Hansen J, Jorgensen JA, Wu J, Mottaghy FM et al. Cold acclimation recruits human brown fat and increases nonshivering thermogenesis. Journal of Clinical Investigation 2013123 3395-3403. (doi:10.1172/JCI68993)

24 Yoneshiro T, Aita S, Matsushita M, Kayahara T, Kameya T, Kawai Y, Iwanaga $\mathrm{T} \&$ Saito $\mathrm{M}$. Recruited brown adipose tissue as an antiobesity agent in humans. Journal of Clinical Investigation 2013123 3404-3408. (doi:10.1172/JCI67803)

25 Au-Yong IT, Thorn N, Ganatra R, Perkins AC \& Symonds ME. Brown adipose tissue and seasonal variation in humans. Diabetes $2009 \mathbf{5 8}$ 2583-2587. (doi:10.2337/db09-0833)

26 Huang YC, Hsu CC, Wang PW, Chang YH, Chen TB, Lee BF \& Chiu NT. Review analysis of the association between the prevalence of activated brown adipose tissue and outdoor temperature. Scientific World Journal 20122012 793039. (doi:10.1100/2012/793039)

27 Ouellet V, Routhier-Labadie A, Bellemare W, Lakhal-Chaieb L, Turcotte E, Carpentier AC \& Richard D. Outdoor temperature, age, sex, body mass index, and diabetic status determine the prevalence, mass, and glucose-uptake activity of 18F-FDG-detected BAT in humans. Journal of Clinical Endocrinology and Metabolism 201196 192-199. (doi:10.1210/jc.2010-0989)

28 Persichetti A, Sciuto R, Rea S, Basciani S, Lubrano C, Mariani S, Ulisse S, Nofroni I, Maini CL \& Gnessi L. Prevalence, mass, and glucose-uptake activity of (1)(8)F-FDG-detected brown adipose tissue in humans living in a temperate zone of Italy. PLoS ONE 20138 e63391. (doi:10.1371/journal.pone.0063391)

29 Saito M, Okamatsu-Ogura Y, Matsushita M, Watanabe K, Yoneshiro T, Nio-Kobayashi J, Iwanaga T, Miyagawa M, Kameya T, Nakada K et al.
High incidence of metabolically active brown adipose tissue in healthy adult humans: effects of cold exposure and adiposity. Diabetes 200958 1526-1531. (doi:10.2337/db09-0530)

30 Christensen CR, Clark PB \& Morton KA. Reversal of hypermetabolic brown adipose tissue in F-18 FDG PET imaging. Clinical Nuclear Medicine 200631 193-196. (doi:10.1097/01.rlu.0000204199. 33136.05)

31 Garcia CA, Van Nostrand D, Atkins F, Acio E, Butler C, Esposito G, Kulkarni K \& Majd M. Reduction of brown fat 2-deoxy-2-[F-18]fluoroD-glucose uptake by controlling environmental temperature prior to positron emission tomography scan. Molecular Imaging and Biology 20068 24-29. (doi:10.1007/s11307-005-0030-3)

32 Zukotynski KA, Fahey FH, Laffin S, Davis R, Treves ST, Grant FD \& Drubach LA. Constant ambient temperature of 24 degrees C significantly reduces FDG uptake by brown adipose tissue in children scanned during the winter. European Journal of Nuclear Medicine and Molecular Imaging 200936 602-606. (doi:10.1007/s00259-008-0983-y)

33 Ouellet V, Labbe SM, Blondin DP, Phoenix S, Guerin B, Haman F, Turcotte EE, Richard D \& Carpentier AC. Brown adipose tissue oxidative metabolism contributes to energy expenditure during acute cold exposure in humans. Journal of Clinical Investigation 2012122 545-552. (doi:10.1172/JCI60433)

34 Muzik O, Mangner TJ, Leonard WR, Kumar A, Janisse J \& Granneman JG. 15O PET measurement of blood flow and oxygen consumption in cold-activated human brown fat. Journal of Nuclear Medicine 201354 523-531. (doi:10.2967/jnumed.112.111336)

35 Orava J, Nuutila P, Lidell ME, Oikonen V, Noponen T, Viljanen T, Scheinin M, Taittonen M, Niemi T, Enerback S et al. Different metabolic responses of human brown adipose tissue to activation by cold and insulin. Cell Metabolism 201114 272-279. (doi:10.1016/ j.cmet.2011.06.012)

36 Huttunen P, Hirvonen J \& Kinnula V. The occurrence of brown adipose tissue in outdoor workers. European Journal of Applied Physiology and Occupational Physiology 198146 339-345. (doi:10.1007/BF00422121)

37 Hanssen MJ, Hoeks J, Brans B, van der Lans AA, Schaart G, van den Driessche JJ, Jorgensen JA, Boekschoten MV, Hesselink MK, Havekes B et al. Short-term cold acclimation improves insulin sensitivity in patients with type 2 diabetes mellitus. Nature Medicine 201521 863-865. (doi:10.1038/nm.3891)

38 Chen KY, Brychta RJ, Linderman JD, Smith S, Courville A, Dieckmann W, Herscovitch P, Millo CM, Remaley A, Lee P et al. Brown fat activation mediates cold-induced thermogenesis in adult humans in response to a mild decrease in ambient temperature. Journal of Clinical Endocrinology and Metabolism 201398 E1218-E1223. (doi:10.1210/jc.2012-4213)

39 Cypess AM, Chen YC, Sze C, Wang K, English J, Chan O, Holman AR, Tal I, Palmer MR, Kolodny GM et al. Cold but not sympathomimetics activates human brown adipose tissue in vivo. PNAS 2012109 10001-10005. (doi:10.1073/pnas.1207911109)

40 Lee P, Linderman JD, Smith S, Brychta RJ, Wang J, Idelson C, Perron RM, Werner CD, Phan GQ, Kammula US et al. Irisin and FGF21 are cold-induced endocrine activators of brown fat function in humans. Cell Metabolism 201419 302-309. (doi:10.1016/j.cmet.2013. 12.017)

41 Vosselman MJ, Brans B, van der Lans AA, Wierts R, van Baak MA, Mottaghy FM, Schrauwen P \& van Marken Lichtenbelt WD. Brown adipose tissue activity after a high-calorie meal in humans. American Journal of Clinical Nutrition 201398 57-64. (doi:10.3945/ajcn.113. 059022)

42 Shimizu Y, Nikami H, Tsukazaki K, Machado UF, Yano H, Seino Y \& Saito M. Increased expression of glucose transporter GLUT-4 in brown adipose tissue of fasted rats after cold exposure. American Journal of Physiology 1993264 E890-E895. 
43 Cinti S. Between brown and white: novel aspects of adipocyte differentiation. Annals of Medicine 201143 104-115. (doi:10.3109/ 07853890.2010.535557)

44 Fukuchi K, Tatsumi M, Ishida Y, Oku N, Hatazawa J \& Wahl RL. Radionuclide imaging metabolic activity of brown adipose tissue in a patient with pheochromocytoma. Experimental and Clinical Endocrinology \& Diabetes 2004112 601-603. (doi:10.1055/s-2004-830407)

45 Hadi M, Chen CC, Whatley M, Pacak K \& Carrasquillo JA. Brown fat imaging with (18)F-6-fluorodopamine PET/CT, (18)F-FDG PET/CT, and (123)I-MIBG SPECT: a study of patients being evaluated for pheochromocytoma. Journal of Nuclear Medicine 200748 1077-1083. (doi:10.2967/jnumed.106.035915)

46 Wang Q, Zhang M, Ning G, Gu W, Su T, Xu M, Li B \& Wang W. Brown adipose tissue in humans is activated by elevated plasma catecholamines levels and is inversely related to central obesity. PLoS ONE 20116 e21006. (doi:10.1371/journal.pone.0021006)

47 Frontini A, Vitali A, Perugini J, Murano I, Romiti C, Ricquier D, Guerrieri M \& Cinti S. White-to-brown transdifferentiation of omental adipocytes in patients affected by pheochromocytoma. Biochimica et Biophysica Acta 20131831 950-959. (doi:10.1016/j.bbalip.2013. 02.005)

48 Lean ME, James WP, Jennings G \& Trayhurn P. Brown adipose tissue in patients with phaeochromocytoma. International Journal of Obesity 198610 219-227.

49 Ricquier D, Nechad M \& Mory G. Ultrastructural and biochemical characterization of human brown adipose tissue in pheochromocytoma. Journal of Clinical Endocrinology and Metabolism 198254 803-807. (doi:10.1210/jcem-54-4-803)

50 Collins S, Yehuda-Shnaidman E \& Wang H. Positive and negative control of Ucp1 gene transcription and the role of $\beta$-adrenergic signaling networks. International Journal of Obesity 201034 (Suppl 1) S28-S33. (doi:10.1038/ijo.2010.180)

51 Shimizu Y, Nikami H \& Saito M. Sympathetic activation of glucose utilization in brown adipose tissue in rats. Journal of Biochemistry 1991 110 688-692.

52 Deng C, Paoloni-Giacobino A, Kuehne F, Boss O, Revelli JP, Moinat M, Cawthorne MA, Muzzin P \& Giacobino JP. Respective degree of expression of $\beta$ 1-, $\beta 2$ - and $\beta$ 3-adrenoceptors in human brown and white adipose tissues. British Journal of Pharmacology 1996118 929-934. (doi:10.1111/j.1476-5381.1996.tb15488.x)

53 Mattsson CL, Csikasz RI, Chernogubova E, Yamamoto DL, Hogberg HT, Amri EZ, Hutchinson DS \& Bengtsson T. $\beta(1)$-Adrenergic receptors increase UCP1 in human MADS brown adipocytes and rescue cold-acclimated $\beta(3)$-adrenergic receptor-knockout mice via nonshivering thermogenesis. American Journal of Physiology. Endocrinology and Metabolism 2011301 E1108-E1118. (doi:10.1152/ ajpendo.00085.2011)

54 Muzzin P, Revelli JP, Kuhne F, Gocayne JD, McCombie WR, Venter JC, Giacobino JP \& Fraser CM. An adipose tissue-specific $\beta$-adrenergic receptor. Molecular cloning and down-regulation in obesity. Journal of Biological Chemistry 1991266 24053-24058.

55 Puigserver P, Pico C, Stock MJ \& Palou A. Effect of selective $\beta$-adrenoceptor stimulation on UCP synthesis in primary cultures of brown adipocytes. Molecular and Cellular Endocrinology 1996 117 7-16. (doi:10.1016/0303-7207(95)03727-6)

56 Parysow O, Mollerach AM, Jager V, Racioppi S, San Roman J \& Gerbaudo VH. Low-dose oral propranolol could reduce brown adipose tissue F-18 FDG uptake in patients undergoing PET scans. Clinical Nuclear Medicine 200732 351-357. (doi:10.1097/01.rlu.0000259570. 69163.04)

57 Soderlund V, Larsson SA \& Jacobsson H. Reduction of FDG uptake in brown adipose tissue in clinical patients by a single dose of propranolol. European Journal of Nuclear Medicine and Molecular Imaging 200734 1018-1022. (doi:10.1007/s00259-006-0318-9)

58 Cypess AM, Weiner LS, Roberts-Toler C, Franquet Elia E, Kessler SH, Kahn PA, English J, Chatman K, Trauger SA, Doria A et al. Activation of human brown adipose tissue by a $\beta 3$-adrenergic receptor agonist. Cell Metabolism 201521 33-38. (doi:10.1016/j.cmet.2014.12.009)

59 Silva JE. Thermogenic mechanisms and their hormonal regulation. Physiological Reviews 200686 435-464. (doi:10.1152/physrev. $00009.2005)$

60 Lee JY, Takahashi N, Yasubuchi M, Kim YI, Hashizaki H, Kim MJ, Sakamoto T, Goto T \& Kawada T. Triiodothyronine induces UCP-1 expression and mitochondrial biogenesis in human adipocytes. American Journal of Physiology. Cell Physiology 2012302 C463-C472. (doi:10.1152/ajpcell.00010.2011)

61 Rothwell NJ, Stock MJ \& Sudera DK. Changes in adrenoreceptor density in brown adipose tissue from hyperthyroid rats. European Journal of Pharmacology 1985114 227-229. (doi:10.1016/0014-2999 (85)90632-6)

62 Rubio A, Raasmaja A, Maia AL, Kim KR \& Silva JE. Effects of thyroid hormone on norepinephrine signaling in brown adipose tissue. I. $\beta$ 1- and $\beta$ 2-adrenergic receptors and cyclic adenosine 3',5'-monophosphate generation. Endocrinology 1995136 3267-3276. (doi:10.1210/endo.136.8.7628360)

63 Lopez M, Varela L, Vazquez MJ, Rodriguez-Cuenca S, Gonzalez CR, Velagapudi VR, Morgan DA, Schoenmakers E, Agassandian K, Lage R et al. Hypothalamic AMPK and fatty acid metabolism mediate thyroid regulation of energy balance. Nature Medicine 201016 1001-1008. (doi:10.1038/nm.2207)

64 Skarulis MC, Celi FS, Mueller E, Zemskova M, Malek R, Hugendubler L, Cochran C, Solomon J, Chen C \& Gorden P. Thyroid hormone induced brown adipose tissue and amelioration of diabetes in a patient with extreme insulin resistance. Journal of Clinical Endocrinology and Metabolism 201095 256-262. (doi:10.1210/jc.2009-0543)

65 Lahesmaa M, Orava J, Schalin-Jantti C, Soinio M, Hannukainen JC, Noponen T, Kirjavainen A, Iida H, Kudomi N, Enerback S et al. Hyperthyroidism increases brown fat metabolism in humans. Journal of Clinical Endocrinology and Metabolism 201499 E28-E35. (doi:10.1210/jc.2013-2312)

66 Forrest D \& Vennstrom B. Functions of thyroid hormone receptors in mice. Thyroid 2000 10 41-52. (doi:10.1089/thy.2000.10.41)

67 Ribeiro MO, Bianco SD, Kaneshige M, Schultz JJ, Cheng SY, Bianco AC $\&$ Brent GA. Expression of uncoupling protein 1 in mouse brown adipose tissue is thyroid hormone receptor- $\beta$ isoform specific and required for adaptive thermogenesis. Endocrinology 2010151 432-440. (doi:10.1210/en.2009-0667)

68 Ribeiro MO, Carvalho SD, Schultz JJ, Chiellini G, Scanlan TS, Bianco AC \& Brent GA. Thyroid hormone - sympathetic interaction and adaptive thermogenesis are thyroid hormone receptor isoform-specific. Journal of Clinical Investigation $2001 \mathbf{1 0 8}$ 97-105. (doi:10.1172/JCI200112584)

69 Grover GJ, Egan DM, Sleph PG, Beehler BC, Chiellini G, Nguyen NH, Baxter JD \& Scanlan TS. Effects of the thyroid hormone receptor agonist GC-1 on metabolic rate and cholesterol in rats and primates: selective actions relative to 3,5,3'-triiodo-L-thyronine. Endocrinology 2004145 1656-1661. (doi:10.1210/en.2003-0973)

70 Trost SU, Swanson E, Gloss B, Wang-Iverson DB, Zhang H, Volodarsky T, Grover GJ, Baxter JD, Chiellini G, Scanlan TS et al. The thyroid hormone receptor- $\beta$-selective agonist GC- 1 differentially affects plasma lipids and cardiac activity. Endocrinology 2000141 3057-3064. (doi:10.1210/endo.141.9.7681)

71 Resmini E, Farkas C, Murillo B, Barahona MJ, Santos A, Martinez-Momblan MA, Roig O, Ybarra J, Geli C \& Webb SM. Body composition after endogenous (Cushing's syndrome) and exogenous (rheumatoid arthritis) exposure to glucocorticoids. Hormone and Metabolic Research 201042 613-618. (doi:10.1055/s-0030-1255032)

72 Cristancho AG \& Lazar MA. Forming functional fat: a growing understanding of adipocyte differentiation. Nature Reviews. Molecular Cell Biology 201112 722-734. (doi:10.1038/nrm3198)

73 Christ-Crain M, Kola B, Lolli F, Fekete C, Seboek D, Wittmann G, Feltrin D, Igreja SC, Ajodha S, Harvey-White J et al. AMP-activated 
protein kinase mediates glucocorticoid-induced metabolic changes: a novel mechanism in Cushing's syndrome. FASEB Journal 200822 1672-1683. (doi:10.1096/fj.07-094144)

74 Feldman D. Evidence that brown adipose tissue is a glucocorticoid target organ. Endocrinology 1978103 2091-2097. (doi:10.1210/ endo-103-6-2091)

75 Galpin KS, Henderson RG, James WP \& Trayhurn P. GDP binding to brown-adipose-tissue mitochondria of mice treated chronically with corticosterone. Biochemical Journal 1983214 265-268. (doi:10.1042/ bj2140265)

76 Moriscot A, Rabelo R \& Bianco AC. Corticosterone inhibits uncoupling protein gene expression in brown adipose tissue. American Journal of Physiology 1993265 E81-E87.

77 Feve B, Baude B, Krief S, Strosberg AD, Pairault J \& Emorine LJ. Inhibition by dexamethasone of $\beta 3$-adrenergic receptor responsiveness in 3T3-F442A adipocytes. Evidence for a transcriptional mechanism. Journal of Biological Chemistry 1992267 15909-15915.

78 Kiely J, Hadcock JR, Bahouth SW \& Malbon CC. Glucocorticoids down-regulate $\beta$ 1-adrenergic-receptor expression by suppressing transcription of the receptor gene. Biochemical Journal 1994302 (Pt 2) 397-403. (doi:10.1042/bj3020397)

79 Soumano K, Desbiens S, Rabelo R, Bakopanos E, Camirand A \& Silva JE. Glucocorticoids inhibit the transcriptional response of the uncoupling protein-1 gene to adrenergic stimulation in a brown adipose cell line. Molecular and Cellular Endocrinology 2000165 7-15. (doi:10.1016/ S0303-7207(00)00276-8)

80 Hardwick AJ, Linton EA \& Rothwell NJ. Thermogenic effects of the antiglucocorticoid RU-486 in the rat: involvement of corticotropinreleasing factor and sympathetic activation of brown adipose tissue. Endocrinology 1989124 1684-1688. (doi:10.1210/endo-124-4-1684)

81 Barclay JL, Agada H, Jang C, Ward M, Wetzig N \& Ho KK. Effects of glucocorticoids on human brown adipocytes. Journal of Endocrinology 2015224 139-147. (doi:10.1530/JOE-14-0538)

82 Caprio M, Feve B, Claes A, Viengchareun S, Lombes M \& Zennaro MC. Pivotal role of the mineralocorticoid receptor in corticosteroidinduced adipogenesis. FASEB Journal 200721 2185-2194. (doi:10. 1096/fj.06-7970com)

83 Bochud M, Nussberger J, Bovet P, Maillard MR, Elston RC, Paccaud F, Shamlaye C \& Burnier M. Plasma aldosterone is independently associated with the metabolic syndrome. Hypertension $2006 \mathbf{4 8}$ 239-245. (doi:10.1161/01.HYP.0000231338.41548.fc)

84 Fallo F, Veglio F, Bertello C, Sonino N, Della Mea P, Ermani M, Rabbia F, Federspil G \& Mulatero P. Prevalence and characteristics of the metabolic syndrome in primary aldosteronism. Journal of Clinical Endocrinology and Metabolism 200691 454-459. (doi:10.1210/ jc.2005-1733)

85 Giacchetti G, Ronconi V, Turchi F, Agostinelli L, Mantero F, Rilli S \& Boscaro M. Aldosterone as a key mediator of the cardiometabolic syndrome in primary aldosteronism: an observational study. Journal of Hypertension 200725 177-186. (doi:10.1097/HJH.0b013e3280108e6f)

86 Penfornis P, Viengchareun S, Le Menuet D, Cluzeaud F, Zennaro MC \& Lombes $\mathrm{M}$. The mineralocorticoid receptor mediates aldosteroneinduced differentiation of T37i cells into brown adipocytes. American Journal of Physiology. Endocrinology and Metabolism 2000279 E386-E394.

87 Zennaro MC, Le Menuet D, Viengchareun S, Walker F, Ricquier D \& Lombes M. Hibernoma development in transgenic mice identifies brown adipose tissue as a novel target of aldosterone action. Journal of Clinical Investigation 1998101 1254-1260. (doi:10.1172/JCI1915)

88 Viengchareun S, Penfornis P, Zennaro MC \& Lombes M. Mineralocorticoid and glucocorticoid receptors inhibit UCP expression and function in brown adipocytes. American Journal of Physiology. Endocrinology and Metabolism 2001280 E640-E649.

89 Armani A, Cinti F, Marzolla V, Morgan J, Cranston GA, Antelmi A, Carpinelli G, Canese R, Pagotto U, Quarta C et al. Mineralocorticoid receptor antagonism induces browning of white adipose tissue through impairment of autophagy and prevents adipocyte dysfunction in high-fat-diet-fed mice. FASEB Journal 201428 3745-3757. (doi:10.1096/fj.13-245415)

90 Shi H, Seeley RJ \& Clegg DJ. Sexual differences in the control of energy homeostasis. Frontiers in Neuroendocrinology 200930 396-404. (doi:10.1016/j.yfrne.2009.03.004)

91 Rodriguez-Cuenca S, Monjo M, Frontera M, Gianotti M, Proenza AM \& Roca P. Sex steroid receptor expression profile in brown adipose tissue. Effects of hormonal status. Cellular Physiology and Biochemistry 200720 877-886. (doi:10.1159/000110448)

92 Pedersen SB, Bruun JM, Kristensen K \& Richelsen B. Regulation of UCP1, UCP2, and UCP3 mRNA expression in brown adipose tissue, white adipose tissue, and skeletal muscle in rats by estrogen. Biochemical and Biophysical Research Communications 2001288 191-197. (doi:10.1006/bbrc.2001.5763)

93 Rodriguez AM, Monjo M, Roca P \& Palou A. Opposite actions of testosterone and progesterone on UCP1 mRNA expression in cultured brown adipocytes. Cellular and Molecular Life Sciences 200259 1714-1723. (doi:10.1007/PL00012499)

94 Rodriguez-Cuenca S, Monjo M, Gianotti M, Proenza AM \& Roca P. Expression of mitochondrial biogenesis-signaling factors in brown adipocytes is influenced specifically by $17 \beta$-estradiol, testosterone, and progesterone. American Journal of Physiology. Endocrinology and Metabolism 2007292 E340-E346. (doi:10.1152/ajpendo.00175.2006)

95 Fan W, Yanase T, Nomura M, Okabe T, Goto K, Sato T, Kawano H, Kato $\mathrm{S} \&$ Nawata $\mathrm{H}$. Androgen receptor null male mice develop lateonset obesity caused by decreased energy expenditure and lipolytic activity but show normal insulin sensitivity with high adiponectin secretion. Diabetes 200554 1000-1008. (doi:10.2337/diabetes. 54.4.1000)

96 Abelenda M, Nava MP, Fernandez A \& Puerta ML. Brown adipose tissue thermogenesis in testosterone-treated rats. Acta Endocrinologica 1992 126 434-437.

97 Cypess AM, Lehman S, Williams G, Tal I, Rodman D, Goldfine AB, Kuo FC, Palmer EL, Tseng YH, Doria A et al. Identification and importance of brown adipose tissue in adult humans. New England Journal of Medicine 2009360 1509-1517. (doi:10.1056/ NEJMoa0810780)

98 Lee P, Greenfield JR, Ho KK \& Fulham MJ. A critical appraisal of the prevalence and metabolic significance of brown adipose tissue in adult humans. American Journal of Physiology. Endocrinology and Metabolism 2010299 E601-E606. (doi:10.1152/ajpendo.00298.2010)

99 Yoneshiro T, Aita S, Matsushita M, Okamatsu-Ogura Y, Kameya T, Kawai Y, Miyagawa M, Tsujisaki M \& Saito M. Age-related decrease in cold-activated brown adipose tissue and accumulation of body fat in healthy humans. Obesity 201119 1755-1760. (doi:10.1038/ oby.2011.125)

100 Shibata H, Perusse F \& Bukowiecki LJ. The role of insulin in nonshivering thermogenesis. Canadian Journal of Physiology and Pharmacology 198765 152-158. (doi:10.1139/y87-030)

101 Burcelin R, Kande J, Ricquier D \& Girard J. Changes in uncoupling protein and GLUT4 glucose transporter expressions in interscapular brown adipose tissue of diabetic rats: relative roles of hyperglycaemia and hypoinsulinaemia. Biochemical Journal 1993291 (Pt 1) 109-113. (doi:10.1042/bj2910109)

102 Geloen A \& Trayhurn P. Regulation of the level of uncoupling protein in brown adipose tissue by insulin. American Journal of Physiology 1990 258 R418-R424.

103 Ebner S, Burnol AF, Ferre P, de Saintaurin MA \& Girard J. Effects of insulin and norepinephrine on glucose transport and metabolism in rat brown adipocytes. Potentiation by insulin of norepinephrineinduced glucose oxidation. European Journal of Biochemistry $1987 \mathbf{1 7 0}$ 469-474. (doi:10.1111/j.1432-1033.1987.tb13723.x)

104 Marette A \& Bukowiecki LJ. Stimulation of glucose transport by insulin and norepinephrine in isolated rat brown adipocytes. American Journal of Physiology 1989257 C714-C721. 
105 Guerra C, Navarro P, Valverde AM, Arribas M, Bruning J, Kozak LP, Kahn CR \& Benito M. Brown adipose tissue-specific insulin receptor knockout shows diabetic phenotype without insulin resistance. Journal of Clinical Investigation 2001108 1205-1213. (doi:10.1172/ JCI13103)

106 Muntzel MS, Anderson EA, Johnson AK \& Mark AL. Mechanisms of insulin action on sympathetic nerve activity. Clinical and Experimental Hypertension 199517 39-50. (doi:10.3109/10641969509087053)

107 Rahmouni K, Morgan DA, Morgan GM, Liu X, Sigmund CD, Mark AL \& Haynes WG. Hypothalamic PI3K and MAPK differentially mediate regional sympathetic activation to insulin. Journal of Clinical Investigation 2004114 652-658. (doi:10.1172/JCI21737)

108 Geloen A \& Trayhurn P. Regulation of the level of uncoupling protein in brown adipose tissue by insulin requires the mediation of the sympathetic nervous system. FEBS Letters 1990267 265-267. (doi:10.1016/0014-5793(90)80941-B)

109 de Jonge L \& Bray GA. The thermic effect of food and obesity: a critical review. Obesity Research 19975 622-631. (doi:10.1002/j.1550-8528. 1997.tb00584.x)

110 Kinabo JL \& Durnin JV. Thermic effect of food in man: effect of meal composition, and energy content. British Journal of Nutrition 199064 37-44. (doi:10.1079/BJN19900007)

111 Westerterp KR, Wilson SA \& Rolland V. Diet induced thermogenesis measured over $24 \mathrm{~h}$ in a respiration chamber: effect of diet composition. International Journal of Obesity and Related Metabolic Disorders 199923 287-292. (doi:10.1038/sj.ijo.0800810)

112 Rothwell NJ \& Stock MJ. A role for brown adipose tissue in dietinduced thermogenesis. Nature 1979281 31-35. (doi:10.1038/ 281031a0)

113 Tulp OL, Frink R \& Danforth E Jr. Effect of cafeteria feeding on brown and white adipose tissue cellularity, thermogenesis, and body composition in rats. Journal of Nutrition 1982112 2250-2260.

114 Rothwell NJ \& Stock MJ. Effect of chronic food restriction on energy balance, thermogenic capacity, and brown-adipose-tissue activity in the rat. Bioscience Reports 19822 543-549. (doi:10.1007/BF01314214)

115 Kozak LP. Brown fat and the myth of diet-induced thermogenesis. Cell Metabolism 201011 263-267. (doi:10.1016/j.cmet.2010.03.009)

116 Kawada T, Watanabe T, Takaishi T, Tanaka T \& Iwai K. Capsaicin-induced $\beta$-adrenergic action on energy metabolism in rats: influence of capsaicin on oxygen consumption, the respiratory quotient, and substrate utilization. Proceedings of the Society for Experimental Biology and Medicine 1986183 250-256. (doi:10.3181/00379727-183-42414)

117 Clegg ME, Golsorkhi M \& Henry CJ. Combined medium-chain triglyceride and chilli feeding increases diet-induced thermogenesis in normal-weight humans. European Journal of Nutrition 201352 1579-1585. (doi:10.1007/s00394-012-0463-9)

118 Yoshioka M, St-Pierre S, Suzuki M \& Tremblay A. Effects of red pepper added to high-fat and high-carbohydrate meals on energy metabolism and substrate utilization in Japanese women. British Journal of Nutrition 199880 503-510.

119 Yoneshiro T \& Saito M. Transient receptor potential activated brown fat thermogenesis as a target of food ingredients for obesity management. Current Opinion in Clinical Nutrition and Metabolic Care 201316 625-631. (doi:10.1097/MCO.0b013e3283653ee1)

120 Leung FW. Capsaicin as an anti-obesity drug. Progress in Drug Research 201468 171-179.

121 Zhang LL, Yan Liu D, Ma LQ, Luo ZD, Cao TB, Zhong J, Yan ZC, Wang LJ, Zhao ZG, Zhu SJ et al. Activation of transient receptor potential vanilloid type- 1 channel prevents adipogenesis and obesity. Circulation Research 2007100 1063-1070. (doi:10.1161/01.RES. $0000262653.84850 .8 b)$

122 Baboota RK, Singh DP, Sarma SM, Kaur J, Sandhir R, Boparai RK, Kondepudi KK \& Bishnoi M. Capsaicin induces "brite" phenotype in differentiating 3T3-L1 preadipocytes. PLOS ONE 20149 e103093. (doi:10.1371/journal.pone.0103093)
123 Galgani JE \& Ravussin E. Effect of dihydrocapsiate on resting metabolic rate in humans. American Journal of Clinical Nutrition 2010 92 1089-1093. (doi:10.3945/ajcn.2010.30036)

124 Snitker S, Fujishima Y, Shen H, Ott S, Pi-Sunyer X, Furuhata Y, Sato H $\&$ Takahashi M. Effects of novel capsinoid treatment on fatness and energy metabolism in humans: possible pharmacogenetic implications. American Journal of Clinical Nutrition 200989 45-50. (doi:10.3945/ajcn.2008.26561)

125 Yoneshiro T, Aita S, Kawai Y, Iwanaga T \& Saito M. Nonpungent capsaicin analogs (capsinoids) increase energy expenditure through the activation of brown adipose tissue in humans. American Journal of Clinical Nutrition 201295 845-850. (doi:10.3945/ajcn.111.018606)

126 Sugita J, Yoneshiro T, Hatano T, Aita S, Ikemoto T, Uchiwa H, Iwanaga T, Kameya T, Kawai Y \& Saito M. Grains of paradise (Aframomum melegueta) extract activates brown adipose tissue and increases whole-body energy expenditure in men. British Journal of Nutrition 2013110 733-738. (doi:10.1017/S0007114512005715)

127 Vrieze A, Schopman JE, Admiraal WM, Soeters MR, Nieuwdorp M, Verberne HJ \& Holleman F. Fasting and postprandial activity of brown adipose tissue in healthy men. Journal of Nuclear Medicine 201253 1407-1410. (doi:10.2967/jnumed.111.100701)

128 Bostrom P, Wu J, Jedrychowski MP, Korde A, Ye L, Lo JC, Rasbach KA, Bostrom EA, Choi JH, Long JZ et al. A PGC1- $\alpha$-dependent myokine that drives brown-fat-like development of white fat and thermogenesis. Nature 2012481 463-468. (doi:10.1038/nature10777)

129 Huh JY, Panagiotou G, Mougios V, Brinkoetter M, Vamvini MT, Schneider BE \& Mantzoros CS. FNDC5 and irisin in humans: I. Predictors of circulating concentrations in serum and plasma and II. mRNA expression and circulating concentrations in response to weight loss and exercise. Metabolism 201261 1725-1738. (doi:10.1016/j.metabol.2012.09.002)

130 Kraemer RR, Shockett P, Webb ND, Shah U \& Castracane VD. A transient elevated irisin blood concentration in response to prolonged, moderate aerobic exercise in young men and women. Hormone and Metabolic Research 201446 150-154. (doi:10.1055/ s-0033-1355381)

131 Norheim F, Langleite TM, Hjorth M, Holen T, Kielland A, Stadheim HK, Gulseth HL, Birkeland KI, Jensen J \& Drevon CA. The effects of acute and chronic exercise on PGC- $1 \alpha$, irisin and browning of subcutaneous adipose tissue in humans. FEBS Journal 2014281 739-749. (doi:10.1111/febs.12619)

132 Kurdiova T, Balaz M, Vician M, Maderova D, Vlcek M, Valkovic L, Srbecky M, Imrich R, Kyselovicova O, Belan V et al. Effects of obesity, diabetes and exercise on Fndc5 gene expression and irisin release in human skeletal muscle and adipose tissue: in vivo and in vitro studies. Journal of Physiology 2014592 1091-1107. (doi:10.1113/jphysiol.2013. 264655)

133 Pekkala S, Wiklund PK, Hulmi JJ, Ahtiainen JP, Horttanainen M, Pollanen E, Makela KA, Kainulainen H, Hakkinen K, Nyman K et al. Are skeletal muscle FNDC5 gene expression and irisin release regulated by exercise and related to health? Journal of Physiology 2013 591 5393-5400. (doi:10.1113/jphysiol.2013.263707)

134 Hecksteden A, Wegmann M, Steffen A, Kraushaar J, Morsch A, Ruppenthal S, Kaestner L \& Meyer T. Irisin and exercise training in humans - results from a randomized controlled training trial. BMC Medicine 201311 235. (doi:10.1186/1741-7015-11-235)

135 Raschke S, Elsen M, Gassenhuber H, Sommerfeld M, Schwahn U, Brockmann B, Jung R, Wisloff U, Tjonna AE, Raastad T et al. Evidence against a beneficial effect of irisin in humans. PLOS ONE $2013 \mathbf{8}$ e73680. (doi:10.1371/journal.pone.0073680)

136 Kharitonenkov A, Shiyanova TL, Koester A, Ford AM, Micanovic R, Galbreath EJ, Sandusky GE, Hammond LJ, Moyers JS, Owens RA et al. FGF-21 as a novel metabolic regulator. Journal of Clinical Investigation 2005115 1627-1635. (doi:10.1172/JCI23606)

137 Berglund ED, Li CY, Bina HA, Lynes SE, Michael MD, Shanafelt AB, Kharitonenkov A \& Wasserman DH. Fibroblast growth factor 21 
controls glycemia via regulation of hepatic glucose flux and insulin sensitivity. Endocrinology 2009150 4084-4093. (doi:10.1210/ en.2009-0221)

138 Coskun T, Bina HA, Schneider MA, Dunbar JD, Hu CC, Chen Y, Moller DE \& Kharitonenkov A. Fibroblast growth factor 21 corrects obesity in mice. Endocrinology 2008149 6018-6027. (doi:10.1210/ en.2008-0816)

139 Lee P, Werner CD, Kebebew E \& Celi FS. Functional thermogenic beige adipogenesis is inducible in human neck fat. International Journal of Obesity 201438 170-176. (doi:10.1038/ijo.2013.82)

140 Lee P, Brychta RJ, Linderman J, Smith S, Chen KY \& Celi FS. Mild cold exposure modulates fibroblast growth factor 21 (FGF21) diurnal rhythm in humans: relationship between FGF21 levels, lipolysis, and cold-induced thermogenesis. Journal of Clinical Endocrinology and Metabolism 201398 E98-102. (doi:10.1210/jc.2012-3107)

141 Fisher FM, Kleiner S, Douris N, Fox EC, Mepani RJ, Verdeguer F, Wu J, Kharitonenkov A, Flier JS, Maratos-Flier E et al. FGF21 regulates PGC$1 \alpha$ and browning of white adipose tissues in adaptive thermogenesis. Genes \& Development 201226 271-281. (doi:10.1101/gad.177857.111)

142 Chen D, Zhao M, Harris SE \& Mi Z. Signal transduction and biological functions of bone morphogenetic proteins. Frontiers in Bioscience 2004 9 349-358. (doi:10.2741/1090)

143 Elsen M, Raschke S, Tennagels N, Schwahn U, Jelenik T, Roden M, Romacho T \& Eckel J. BMP4 and BMP7 induce the white-to-brown transition of primary human adipose stem cells. American Journal of Physiology. Cell Physiology 2014306 C431-C440. (doi:10.1152/ajpcell. $00290.2013)$

144 Sharma A, Huard C, Vernochet C, Ziemek D, Knowlton KM, Tyminski E, Paradis T, Zhang Y, Jones JE, von Schack D et al. Brown fat determination and development from muscle precursor cells by novel action of bone morphogenetic protein 6. PLoS ONE 20149 e92608. (doi:10.1371/journal.pone.0092608)

145 Inuzuka M, Tamura N, Yamada N, Katsuura G, Oyamada N, Taura D, Sonoyama T, Fukunaga $\mathrm{Y}$, Ohinata $\mathrm{K}$, Sone $\mathrm{M}$ et al. C-type natriuretic peptide as a new regulator of food intake and energy expenditure. Endocrinology 2010151 3633-3642. (doi:10.1210/en.2010-0141)

146 Bordicchia M, Liu D, Amri EZ, Ailhaud G, Dessi-Fulgheri P, Zhang C, Takahashi N, Sarzani R \& Collins S. Cardiac natriuretic peptides act via p38 MAPK to induce the brown fat thermogenic program in mouse and human adipocytes. Journal of Clinical Investigation $2012 \mathbf{1 2 2}$ 1022-1036. (doi:10.1172/JCI59701)

147 Feldmann HM, Golozoubova V, Cannon B \& Nedergaard J. UCP1 ablation induces obesity and abolishes diet-induced thermogenesis in mice exempt from thermal stress by living at thermoneutrality. Cell Metabolism 20099 203-209. (doi:10.1016/j.cmet.2008.12.014)

148 Kontani Y, Wang Y, Kimura K, Inokuma KI, Saito M, Suzuki-Miura T, Wang Z, Sato Y, Mori N \& Yamashita H. UCP1 deficiency increases susceptibility to diet-induced obesity with age. Aging Cell 20054 147-155. (doi:10.1111/j.1474-9726.2005.00157.x)

149 Lowell BB, V SS, Hamann A, Lawitts JA, Himms-Hagen J, Boyer BB, Kozak LP \& Flier JS. Development of obesity in transgenic mice after genetic ablation of brown adipose tissue. Nature 1993366 740-742. (doi:10.1038/366740a0)

150 Park JY, Lim JS, Park EY, Cho AR, Kim BI, Cheon GJ, Choi CW \& Lim SM. The prevalence and characteristics of brown adipose tissue in an (18)F-FDG PET study of koreans. Nuclear Medicine and Molecular Imaging 201044 207-212. (doi:10.1007/s13139-010-0042-z)

151 Zhang Z, Cypess AM, Miao Q, Ye H, Liew CW, Zhang Q, Xue R, Zhang S, Zuo C, Xu Z et al. The prevalence and predictors of active brown adipose tissue in Chinese adults. European Journal of Endocrinology 2014170 359-366. (doi:10.1530/EJE-13-0712)

152 Vijgen GH, Bouvy ND, Teule GJ, Brans B, Schrauwen P \& van Marken Lichtenbelt WD. Brown adipose tissue in morbidly obese subjects. PLOS ONE 20116 e17247. (doi:10.1371/journal.pone.0017247)

153 Yoneshiro T, Aita S, Matsushita M, Kameya T, Nakada K, Kawai Y \& Saito M. Brown adipose tissue, whole-body energy expenditure, and thermogenesis in healthy adult men. Obesity 2011 19 13-16. (doi:10.1038/oby.2010.105)

154 Bartelt A, Bruns OT, Reimer R, Hohenberg H, Ittrich H, Peldschus K, Kaul MG, Tromsdorf UI, Weller H, Waurisch C et al. Brown adipose tissue activity controls triglyceride clearance. Nature Medicine 201117 200-205. (doi:10.1038/nm.2297)

155 Astrup A, Bulow J, Christensen NJ \& Madsen J. Ephedrine-induced thermogenesis in man: no role for interscapular brown adipose tissue. Clinical Science 198466 179-186. (doi:10.1042/cs0660179)

156 Vosselman MJ, van der Lans AA, Brans B, Wierts R, van Baak MA, Schrauwen P \& van Marken Lichtenbelt WD. Systemic $\beta$-adrenergic stimulation of thermogenesis is not accompanied by brown adipose tissue activity in humans. Diabetes 201261 3106-3113. (doi:10.2337/ db12-0288)

157 Carey AL, Formosa MF, Van Every B, Bertovic D, Eikelis N, Lambert GW, Kalff V, Duffy SJ, Cherk MH \& Kingwell BA. Ephedrine activates brown adipose tissue in lean but not obese humans. Diabetologia 201356 147-155. (doi:10.1007/s00125-012-2748-1)

158 Lee P, Day RO, Greenfield JR \& Ho KK. Formoterol, a highly $\beta 2$ selective agonist, increases energy expenditure and fat utilisation in men. International Journal of Obesity 201337 593-597. (doi:10.1038/ ijo.2012.90)

159 Jang C, Jalapu S, Thuzar M, Law PW, Jeavons S, Barclay JL \& Ho KK. Infrared thermography in the detection of brown adipose tissue in humans. Physiological Reports 20142 e12167. (doi:10.14814/phy2. 12167)

160 Lee P, Ho KK, Lee P, Greenfield JR, Ho KK \& Greenfield JR. Hot fat in a cool man: infrared thermography and brown adipose tissue. Diabetes, Obesity \& Metabolism 201113 92-93. (doi:10.1111/j.1463-1326.2010. 01318.x)

161 Symonds ME, Henderson K, Elvidge L, Bosman C, Sharkey D, Perkins AC \& Budge $\mathrm{H}$. Thermal imaging to assess age-related changes of skin temperature within the supraclavicular region co-locating with brown adipose tissue in healthy children. Journal of Pediatrics 2012 161 892-898. (doi:10.1016/j.jpeds.2012.04.056)

162 Chen YI, Cypess AM, Sass CA, Brownell AL, Jokivarsi KT, Kahn CR \& Kwong KK. Anatomical and functional assessment of brown adipose tissue by magnetic resonance imaging. Obesity 201220 1519-1526. (doi:10.1038/oby.2012.22)

163 Reddy NL, Jones TA, Wayte SC, Adesanya O, Sankar S, Yeo YC, Tripathi G, McTernan PG, Randeva HS, Kumar S et al. Identification of brown adipose tissue using MR imaging in a human adult with histological and immunohistochemical confirmation. Journal of Clinical Endocrinology and Metabolism 201499 E117-E121. (doi:10.1210/jc.2013-2036)

Received 15 December 2015

Revised version received 25 January 2016

Accepted 9 February 2016 